Tattva, Vol. 3, No. 1, January - June 2011, pp. 1-13 ISSN 0975-332X | https://doi.org/10.12726/tjp.5.1

Tattua

JOURNAL OF PHILOSOPHY

\title{
MYSTICISM YESTERDAY, TODAY, TOMORROW: THE INTERSECTION OF THE TIMELESS WITH TIME
}

\section{Bernard McGinn, Ph.D}

In his Four Quartets, the greatest mystical poem of the twentieth century, T. S. Eliot has these well-known lines:

But to apprehend

The point of intersection of the timeless

With time, is an occupation for the saint-

No occupation either, but something given

And taken, in a lifetime's death in love

Ardour and selflessness and self-surrender!'

This paper will be a meditation on these lines, more specifically a consideration of how mysticism involves the intersection of the timeless with time, as well as the simultaneity of the point and infinity. These intersections, I believe, are defining marks of mysticism - yesterday, today, and tomorrow.

T. S. Eliot, "The Dry Salvages," in Four Quartets. London: Faber \& Faber, 1959, 44. For studies, Paul Murray, T. S. Eliot and Mysticism. The Secret History of "Four Quartets." New York: St. Martin's Press, 1991; Michael Spencer, "Mysticism in T. S. Eliot's Four Quartets," Studies in Spirituality 9 (1999): 230-66; and Kenneth Paul Kramer, Redeeming Time: T. S. Eliot's Four Quartets. Lanham, MD: Cowley Publications, 2006. 
Mysticism is a modern term created by Western scholars of religion, though with roots in Christian use of the qualifier mustikos (hidden) in such phrases as sensus mysticus, contemplatio mystica, and theologia mystica. ${ }^{2}$ Nevertheless, many faith traditions have been willing to use the word mysticism as a way of pointing to the importance of deeper consciousness of the divine presence as a life-transforming process, however differently this is conceived across traditions. Some students of mysticism have seen mysticism as essentially a way to escape from the constraints of quotidian life and the temporal process in order to encounter God in the timeless now of divine efernity. Mysticism, therefore, has been viewed as the core of religion, a union with God that is essentially the same across all faiths, however varied its expressions. On the other hand, other scholars have emphasized that mysticism is contextual and has always constituted a threat, implicit or explicit, to the established temporal structures of religions - earned, legal, and institutional.

All three of these views have elements of truth, but taken in isolation none of them captures the full meaning of the phenomenon. Mysticism is a complex and contentious phenomenon that resists single-minded reductions. In this talk I will touch on only one issue, examining mysticism, or what I prefer to call "the mystical element of religion," as containing both a temporal and an eternal dimension, as well as a particular and universal aspect.

Mysticism as a phenomenon within a particular religion and as an aspect of religion in general always has a temporal dimension. Within any religious tradition we can say that however much some mystics and forms of mysticism may aim for an escape from time, the attainment of this goal is itself realized only through time, that is, as part of a temporal process involving, most often, long periods of preparation, some form of attainment of the desired goal of finding God, as well as a return to temporality and a commitment to live in a way that manifests the effects of the encounter with God or the Ultimate. This is why most mystics have sought to spread their message to others. The historical dimension of the mystical process, as well as the temporal dimension of the impact the mystics have had is what makes it possible to write histories of Hindu mysticism, Buddhist mysticism, Jewish mysticism, Christian mysticism, or Islamic mysticism.

2 For a brief history of the ferm, see Louis Bouyer, "Mysticism. An Essay on the History of the Word," in Understanding Mysticism, ed. Richard Woods, OP. Garden City: Doubleday, 1980, 42-55.

3 For an argument supporting the language of "the mystical element of religion" (an expression I take over from Friedrich von Hügell, see Bernard McGinn, The Foundations of Mysticism. Origins to the Fifth Century. New York: Crossroad, 1991, xvi. 
Different traditions approach the importance of this historical dimension in diverse ways that I hope may become part of our discussions at this conference. Here I will restrict my remarks to my own tradition, that is, to some considerations on the intersection of the timeless with time in the history of Christian mysticism. In Christian belief human beings have no power to attain the higher, eternal world on their own. What makes contact with God possible is God's initiative of coming into time, particularity, and corporality. Christians believe that God became human in Jesus Christ, entering human history both in his short life in Palestine two millennia ago, as well as in his continuing temporal existence in the church. ${ }^{4} \mathrm{Hence}$, within Christianity mysticism cannot, by definition, be an ahistorical or static reality, but must be an evolving phenomenon helping to complete the Body of Christ, as the great twentieth-century mystic Pierre Teilhard de Chardin realized so well. The historical evolution of mysticism, no less than the development of doctrine, issues a strong challenge to those who try to view Christianity as an unchanging, ideal reality without serious mutation and change. Within the context of what the late Ewert Cousins called the emergence of "world spirituality," the changes to come in Christian mysticism as it interacts in ever more complex fashion with other traditions during the twenty-first century, will probably be even greater than those of the past. But what does it mean for Christian mysticism to have evolved and developed and how does this involve the intersection of the timeless with time?

My reflections on this issue come from my own attempt over several decades to write a history of Christian mysticism, ${ }^{6}$ as well as a consideration of some specific themes developed by mystical authors. For me studying and writing about the evolution of Christian mysticism has been a process both reassuring and surprising. When I first conceived of writing a history of Christian mysticism, I had a number of convictions, perhaps better surmises, about the shape and intent of the project. Some of these have been confirmed in the actual process of writing. Among these was my sense that no form of Christian mysticism should ever be considered as final or normative - all the vibrant mystics and groups of mystics, especially when seen in their contexts, are historical instantiations of the supreme core of Christian mysticism, the prime intersection of the timeless and time in the life of Christ. ${ }^{7} \mathrm{~A}$

4 For interesting modern reflections on the Incarnation and the spatio-temporal world, see Thomas Torrance, Space, Time and Incarnation. Oxford: Oxford University Press, 1969, especially $74-76$.

5 See Ewert H. Cousins, Global Spirifuality. Toward the Meeting of Mystical Paths. Madras: Radhakrishnan Instifute of the University of Madras, 1985.

- Bernard McGinn, The Presence of God. A History of Western Christian Mysticism. New York: Crossroad-Herder, 1991-. 4 vols, to date.

7 See Hans Urs von Balthasar, "Spirituality," in Explorations in Theology. 1. The Word Made Flesh. San Francisco: Ignatius Press, 1989, 211-26. 
major structural motif of my approach from the outset, however, has proven richer and more surprising than I originally thought.

My initial supposition about the development of Christian mysticism was that it could be structured according to three great layers, sediments, or strata - a kind of geological model. Over the foundation set down in scripture and the faith of the church (itself never static), the first major level of the mystical tradition was what can be termed monastic mysticism, in the sense that it found its first formal expression in the thought of Origen of Alexandria, the great proto-monastic exegete and theologian of the third century. Monastic mysticism found its institutional matrix in the development of the form of life we call "monasticism" in the fourth century. This assured it a location in society and an historical situation and continuity that allowed its proliferation in East and West. In Western Christianity, the twelffh century, known as the era of the birth of Scholastic theology, is now equally famous as being the golden age of monastic theology and mysticism.

Something extraordinary happened around the year 1200 in the West. Social, cultural, and religious forces suddenly helped initiate a new layer of mysticism, novel forms of encountering God characterized by democratization (being expressly open to all believers), secularization (capable of being realized outside the cloister), and vernacularization (expressed in the expanding vernacular literatures). This new layer, or sediment, was birthed within the context of experiments in religious life, especially the mendicants and the beguines, and was noteworthy because, for the first time in Christian histony, women played a preponderant part. It also witnessed the creation (sometimes also the resuscitation) of mystical themes and forms of language not found in traditional.monastic mysticism, a prime example being the possibility of attaining a deep union of identity with God, at least on some level. A less happy consequence was the beginning of tensions between mystical teachers and the institutional guardians of orthodoxy, a topic of great complexity that $I$ can only mention here. ${ }^{8}$ This layer of what I have called "The New Mysticism" formed the second major stage in the story of Western Christian mysticism, one that bridged the gap of the split of Western Christendom into the mutually-contending worlds of Roman Catholicism and Protestantism in the sixteenth century.

Nevertheless, it also seemed clear to me from the beginning of my work that Western Christian mysticism has undergone a third major shift in the Early Modern period. This level, which I've referred to as the "Crisis of Mysticism," is still with us, though

8 For more on this, Bernard McGinn, "Evil-Sounding, Rash, and Suspect of Heresy': Tensions between Mysticism and Magisterium in the History of the Church," Catholic Historical Review 90 (2004): 193-212. 
developments in the fwentieth century begin to suggest that we can speak of it as a stratum of both crisis and renewal. Battered by internal forces, especially the papal condemnation of "Quietistism," the primary form of late seventeenth-century mysticism, and undercut from without by the rise of the Enlightenment rationalistic view of human nature and destiny, mysticism as a living intellectual force collapsed in the eighteenth and nineteenth centuries. This, was, however, a vibrant time for Eastern Christian mysticism in Russia. It was not until around 1900 that new (often non-theological) interest in mysticism opened up the possibility for a rebirth, one that has continued to grow in the past century due to three sources. The first was the emergence of important mystical teachers, both within and without the formal religious world ("unchurched mysticism"); the second was the flowering of the study of mysticism in many disciplines (theology, philosophy, psychology, etc.); the third was the emergence of interreligious dialogue on mysticism, which, despite considerable input from adherents of many traditions, may be said to be still in its infancy. ${ }^{9}$

What a deepening awareness of the nature of this three-layered model has revealed to me is the extent of the interactive nature of the levels. In the mystical tradition, because the teachings of the mystics deal with attempts to find the hidden God and to express this ineffable contact to others, we see an ongoing intersection of the timeless with time. All the writings, sayings, and practices of the mystics are temporal and cultural constructions that can be looked on as evidence for the study of past societies and religions. Yet there is more. Because the various mystics and forms of mysticism represent attempts, impossible but necessary, to speak of what lies beyond human time and space, they contain core insights that both challenge and instruct current believers who are drawn by the same desire to find deeper contact with the divine. Mystical teaching has a presentiality that is different in nature from the doctrinal and legal pronouncements of the past.

Though every religion depends on the process of the handing on of truths and practices - what Christians call tradition-the mystical tradition seems to have a special form of tradition. This is visible in the way in which past and present have interacted in the formation of the various layers and types of mysticism. The three great layers that I have pointed to were to some extent successive, but it is more important to note that they have always interacted, both in the past and in the present. For example, the New Mysticism that began about 1200 did not cancel out the importance of the monastic mysticism that preceded it-it grew out of it and

9 For some reflections on this new development and its possible future, Bernard McGinn, "The Venture of Mysticism in the New Millennium," New Theology Review 21 (2008): 70-79. 
continued to feed upon it for its own vitality. Meister Eckhart, one of the most original of Christian mystics, for all his freshness, is not fully comprehensible without understanding how he used the mysticism of Pseudo-Dionysius to find ways of expressing the union of God's ground and the soul's ground. Other fourteenthcentury mystics, such as the English canon Walter Hilton, nourished themselves on the riches of the twelfth-century Cistercian and Victorine mystics in order to give shape and order to the mystical teaching of the late Middle Ages. In mid-twentiethcentury Christianity it was a monastic mystic, Thomas Merton, who did more than anyone to help spread the message of the importance of contemplation to a broad audience. In short, what has continued to surprise me is how the temporal unfolding of Christian mysticism provides a richer and richer symphonic whole precisely because each of the major levels can still provide living resources for what has come after. Theologically, the source of this ongoing vitality lies in the way in which the great mystics have come into contact with timeless Truth and been able to convey something of this in their writings. The great scholar of Jewish mysticism, Gershom Scholem, recognized this when he said that the mystic not only hands on a religious tradition, but also claims to have had direct contact with the source of the tradition, which is why Scholem argued that for the most part mystics have revitalized the religious traditions in which they stand, rather than challenging or seeking to overturn them. ${ }^{10}$

The Christian mystics provide intriguing insights into the mystery of the intersection of the timeless and time and of the concrete here and the infinite there. Here I will concentrate on how some late medieval mystics used terms and images regarding limits, or limit situations, specifically "point," "rim," and "atom," to express the intersection of the human and divine realms. These terms, to be sure, have different valences, but they all can be used to express insights about the temporal and the spatial aspects of the meeting of creation and the Creator. A more detailed study of such words and their use would reveal further observations on this perhaps overlooked aspect of the history of mysticism. Let me start with two great mystics who were almost exact contemporaries, Dante Alighieri (1261-1321) and Meister Eckhart (ca. 1260-1328).

Dante's Commedia, composed from about 1308 to 1320 , is many things, not least a mystical poem, especially the Paradiso. The poem is a journey through time and space, both in the personal sense of recounting the story of Dante the pilgrim, and in the universal sense of containing an entire cosmology and a history of salvation, beginning from the pilgrim's lostness in sin, nel mezzo di cammin di

10 Gershom Scholem, "Mysticism and Society," Diogenes 58 (1967): 1-24. 
nostra vita (Inf. 1.1), through the circles of hell, purgatory, and heaven, finally to fruition in the vision of the eternal l'amor che move il sole e l'altre stelle (Par. 33.145). " Contrary to some recent critics who want to make Dante into a deconstructionist avant le lettre, I think that we need to take the poet's acceptance of medieval belief seriously, not least his claims that he actually knows whereot he speaks when he says he went to heaven. In his letter to Can Grande della Scala, Dante claims, like Paul in 2 Corinthians 12:2-4, to have journeyed to heaven. Speaking of himself in the third person (again like Paul), he says that "the author" "[...] saw certain things which the one who descends from there [i.e., heaven] is powerless to relate," because "[...] 'the intellect plunges itself to such a depth' in its very longing, which is for God, 'that memory cannot follow'." Thus, "memory fails, since it has transcended the range of human faculty." 22 Similar claims to be like Paul are found throughout the Paradiso. The point of such claims is not to debate whether or not Dante the author did indeed assert he had gone to heaven, but to realize that the theological and mystical intent of the poem is to show the readers how they should see their lives partaking of the same journey toward eternity as Dante the pilgrim. Again, the letter to Can Grande says, "... the purpose of the whole [poem] and the part [Paradiso] is to separate those living in this life from the state of misery and to lead them to the state of heavenly joy. ${ }^{\prime 13} \mathrm{Or}$, in the words of Par. 1.70-72, although "passing beyond humanity (trasumanar) may not be set forth in words, therefore, let the example suffice for any for whom grace reserves that experience." The Commedia is a true fiction in the sense that it presents the true meaning of an individual life as an exemplification of the destiny of humanity realized through the Incarnation. The poem not only contains mystical teaching; it embodies theologia mystica in its intricate web of positive and negative language about God designed to lead the reader beyond the temporal and the local world into the eternal and the infinite realm.

Some key themes in the Paradiso are of particular importance for showing how Dante understood the intersection of the timeless and time. Here I only have time to look at one, the notion of the punto (point), the infinitesmal spot or place where the finite creation crosses over into infinity, which is also where time yields to eternity. In his upward movement through space and time, as well as the sempiternal aevum

" For a text and translation, see Dante Aligheri. The Divine Comedy, 4 vols. trans. by Charles S. Singleton. Princeton: Princeton University Press, 1982.

12 Dante's Epistola XIII to Can Grande della Scala can be found in Paget Toynbee, ed., Dante Aligheris Epistolae. The Letters of Dante. Oxford: Clarendon Press, 1966, where the letter, however, is numbered as X. This passage is from X.28 (ed., 189-90; trans., 208-09). The poet is commenting on and citing Par. 1.7-9. 
that mediates between time and eternity, Dante finally reaches the primum mobile, the first created sphere that provides motion to all the lower spheres. Gazing at the rapidly-revolving primum mobile in Paradiso 28.16-18, he says, "I saw a point which radiated a light so keen that the eye on which it blazes needs must close because of its great keenness." As Christian Moevs has shown, this punto is God in the sense of "the indivisible irreducible unity, a measure of space and time reduced to infinity, to the dimensionless," and therefore the punto represents "the nexus between the world and its ground of being, between the multiplicity of creation and the self-subsistent reality in which it consists. ${ }^{.14}$ (This is why Dante also associates the punto with the Incarnate Word.) Later in the canto Dante goes on to say "...from that punto... depends heaven and all nature" (Par. 28.41-42), and he describes how the choirs of heaven sing "to that fixed point (punto fisso) which holds and shall ever hold them to the 'where' (ubi) in which they have ever been" (Par. 28.9596). This point is God, but not God in God's trinitarian nature, something that the pilgrim will not see until he has passed over into the eternal heavenly empyreum in Cantos 30-33. The punto is God as the intersection of time and eternity, the paradoxical coincidence of the dimensionless point and the universe that depends upon it (see Par. 29.1 - 18). As Dante summarizes in Canto 30.1 1-12: "Not otherwise the triumph which always plays around the point that overcame me (al punto che mi vinse), seeming to be embraced by that which it embraces."

Dante's German contemporary, the Dominican Meister Eckhart, can be read as preaching a message of fleeing time, space, and all particularity in order to plunge into das einic ein, the "Single/Only One" of the ground in which God and the soul are identical. The Eckhartian poem called the Granum sinapis, for example, commands the reader: "Drive away all something, all nothing/Leave place, leave time, avoid images too.../ Sink all my something into God's nothing, / Sink in the bottomless flood!"15 The friar's full message, however, is deeper and more complex, not a final simple flight from time and multiplicity, but a dialectic of detaching and regaining, a willingness to surrender all things in order to find them in a new way.

Eckhart's imperative of detachment and divesting oneself of all things, even selfidentity, holds out a promise that total detachment (abgescheidenheit) and letting-

14 Christian Moevs, "Il puno che mi vinse: Incarnation, Revelations, and Self-Knowledge in Dante's Commedia," in Dante's 'Commedia'. Theology as Poetry, ed. Vittorio Montemaggi and Matthew Treherne. Notre Dame: University of Notre Dame, 2010, pp. 267-76 (quotations at 267, and 270), as well as Moevs's The Metaphysics of Dante's "Commedia" Cambridge: Cambridge University Press, 2005, Chap. 5.

15 I use my translation found in The Essential Writings of Christian Mysticism. New York: Random House, 2006, 295. 
go (gelassenheit) make it possible to fulfill the Pauline command of realizing in our own lives Christ's coming "in the fullness of time" (Gal. 4:4). In German Sermon 38 , for example, Eckhart interprets Paul's fullness of time (plenitudo temporis) not only as the soul's essential independence from time, but also as the gathering up of the whole of history into the present moment, that is, into the "now of eternity in which the soul knows all things in God new and fresh and present and joyous as I have now at present. "16 Thus, Eckhart reminds his hearers that, like Christ, they possess the fullness of time within the eternity present in their ground, if only they can come to recognize this and live their lives on the basis of this truth. What it means to realize the "fullness of time" within daily existence is, I think, made clear by the Dominican's notion of learning to "live without a why" (sonder/âne warumbe), that is, to live like God, who has no "why." ${ }^{17}$ This is to live in time from the perspective of eternity. The person who lives "without a why," like God, is no longer constrained by the whys and wherefores of doing things for any external purpose, but only acts out of an expression of inner joy and overflowing goodness. Living "without a why" helps us understand why Eckhart's mysticism, though it insists that separation from time and the world is necessary, can also be accurately, if paradoxically, described as a "this-worldly mysticism." 18

These reflections on the relation of time and eternity in Eckhart lead to the consideration of another aspect of his preaching that has long been a puzzle. German Sermon 86 has been seen as one of Eckhart's most profound homilies, but has also been a problem due to its obscurity and differences in vocabulary (and sometimes themes) from his other preaching. ${ }^{19} \mathrm{In}$ this sermon the preacher exegetes the story of Mary and Martha from Luke 10. Traditionally, the account had been read as teaching the superiority of the contemplative life, as represented by Mary, but Eckhart argues for the superiority of the life that combines active, practical service and contemplative desire as figured in Martha. The preacher mounts numerous arguments, exegetical and theological, for the superiority of Martha's role. Among these is Eckhart's analysis of why Jesus called out Martha's name

16 Meister Eckhart, Pr. 38 (DW 2:231-32). The same interpretation of Gal. 4:4 is found in Prr. 4, 11 , and 24 (DW 1:74, 177-78, 422-23), and in the Latin works in In lo. n. 293 (LW 3:245).

1 On living "without a why," see Bernard McGinn, The Mystical Thought of Meister Eckhart. New York: Crossroad, 2001, 147-61.

18 Reiner Schürmann, Meister Eckhart. Mystic and Philosopher. Bloomington: Indiana University Press, 1978, 47, 109-10.

19 Pr. 86 can be found in DW 3:481-92. I use the translation of Frank Tobin in Meister Eckhart. Teacher and Preacher, ed. Bernard McGinn. New York: Paulist Press, 1986, 338-45. There is an extensive commentary on this sermon; see especially Dietmar Mieth, Der Einheit von Vita Activa und Vita Passiva in den deutschen Predigten und Traktaten Meister Eckharts und bei Johannes Tauler. Regensburg: Pustet, 1969. 
twice (Lk 10:41). According to Eckhart, the first "Martha" referred to her "perfection in temporal works," while the second indicated that she did not lack anything necessary for eternal happiness. Eckhart praises Martha by saying that she stands in the midst of things but they do not reside in her. Therefore, she is one of the "unimpeded people" (âne hundernisse), who "stand in the midst of things but not in things." Eckhart continues, "They stand very near and yet do not have any less of it than if they stood up there, at the rim of eternity" (umberinge der êwichkeit). Therefore, Martha is also said to have "redeemed the times" (Eph. 5:16), "by continually ascending by means of the mind to God; not according to different images, but by means of living intellectual truth." Although this ascent might seem to abstract her from time and space, its goal is described as "standing above all things, yet under God, on the rim of eternity."

What is this mysterious "rim of eternity"? The sermon tries to explain by distinguishing three modes of attaining God: first, seeking God through creatures; second, a "pathless path... beyond self and all things, beyond will and images"; and finally, "a path that is yet a being-at-home. It is to see God is his ownness" (sinesheit), as Christ did when he said "I am the way, the truth, and the life" (Jn. 14:6). ${ }^{20}$ The sermon identifies the "rim of eternity" with the second mode, a direct contact with God that is nevertheless lower than the unmediated vision of the divine sinesheit, not unlike Dante seeing the divine punto that is not yet the vision of the Trinity. The "rim of eternity," then, might be said to be another way of expressing where time and eternity intersect. ${ }^{21}$ If the umberinge der êwichkeit can serve as a spatiotemporal metaphor for this encounter, it is important to remember that for Eckhart, as for all Christian mystics, it is always the Incarnate Word who effects this coincidence of opposites. In German Sermon 91 he says, "God brings eternity into time and with himself brings time into eternity. This takes place in the Son, when the Son pours himself out in eternity, then all creatures are poured out with him." ${ }^{22}$

Two English mystics from the end of the fourteenth century provide us with more insight on how mystical authors struggled to find words to express the convergence of the domains of time and eternity. The anonymous author of the Cloud of Unknowing wrote in the last decade of the fourteenth century. The visionary Julian of Norwich was given her showings in 1363, wrote them down not long afterwards as $A$ Vision showed to a Devout Woman, and, after many years reflecting on the

D These passages are taken from $\operatorname{Pr} 86$ (DW 3:485-87; trans. 340-41). The expression umberinge der êwichkeit, found five times here, does not occur elsewhere in Eckhart's corpus.

2 Eckhart's "rim of eternity". is so obscure that little comment has been given it.

$2 \operatorname{Pr} 91$ (DW 4:96). 
theological meaning of the visions, completed the Long Version of her text, entitled A Revelation of Love, in the early fifteenth century. Both mystics sought to convey what it means to find eternity in the midst of time.

The author of The Cloud of Unknowing introduces his special exercise of "lifting up the heart to God with a humble impulse of love" in Chapters 3-6 of the treatise. ${ }^{23}$ His teaching about how to put a "cloud of unknowing" between oneself and created reality and to strike against the divine cloud of darkness and unknowing "with a sharp dart of longing love" (Chap. 6) is well known. Less studied is how these chapters contain a profound doctrine on the role of time in the exercise of seeking God. The prayer exercise he teaches, according to the author, "does not need a long time before it can be done, as some men seem to think." Rather, "It is the shortest possible exercise that men can imagine. It is neither longer not shorter than an atom (athomus)," which, according to the "good philosophers in the science of astronomy, is the smallest particle of time. It is so little that, because of its littleness, it is indivisible and almost inconceivable" (undepartable and neighonde incomprehensible) $\cdot{ }^{24}$ Echoing Anselm's Meditations, the author says that God will ask us to give an account of all our time, and that such an account "is neither longer nor shorter but exactly equal to each single stirring that is in the chief working power of your soul, that is, the will." Each impulse of love that seeks to attain God is therefore no more nor less than an atom of time. God gives the soul its time atom-by-atom and it is within this "indivisible and almost inconceivable" instant that we either find God or forget him by a direct, vertical relationship. Human weakness cannot expect to be attentive to all these instants $(22,560$ atoms per hour in medieval reckoning!). Therefore, the only way to be assured of finding God in each atom of time is "for the love of Jesus." The intersection of time and eternity is once again Christological: "So love Jesus and everything that he has is yours. By his Godhead he is the maker and giver of time. By his manhood he is truly the keeper of time. And by his Godhead and manhood together he is the truest judge and accountant of the spending of time. ${ }^{\prime 25}$

The Cloud author's contemporary, the anchoress Julian of Norwich, also reflected on how God intersects with space and time. In the account of the third revelation at the beginning of Chapter 11 of the Long Version she says: "And after this I saw

B For an edition, The Cloud of Unknowing and Related Treatises on Contemplative Prayer, ed. Phyllis Hodgson. Exeter: Catholic Records Press, 1982. I use the translation in The Cloud of Unknowing, ed. James Walsh. New York: Paulist Press, 1981.

24 Cloud, Ch. 4 (ed., 10; trans. adapted, 121-22).

它

Ch. 4 (ed., p. 12; trans., 125). 
God in a point- - that is to say in my understanding - - by which sight I saw that he is in all things. I beheld attentively seeing and knowing in that sight that he does all that is done. I marveled in that sight with a soft dread and thought, "What is $\sin ?^{\prime \prime 26}$ The point in which Julian sees God is spatial and seems to have some relationship to her earlier vision of the world as a small hazelnut (Chap. 5. 7-13; ed. p. 139), but her meditation on the meaning of the vision moves on to a temporal plane- the difference between God's seeing of all things simultaneously in eternity and our temporal existence in which things seem to happen by chance. She says, "For the things that are in the foreseeing wisdom of God from without beginning, which rightfully and with dignity and continually he leads to the best end as they come about, fall upon us suddenly, ourselves unknowing." 27 She concludes this first section of her analysis of the vision by insisting that she sees God, but not in God's self apart from creation: "For in this time the working of creatures was not showed, but of our Lord God in the creature. For he is in the mid-point of all things, and all he does, and I was sure that he does no $\sin ^{\prime \prime}$ (Chap. 11.15-17). In other words, Julian is seeing God in creatures, though from God's perspective in a pointe. Roland Maissoneuve summarizes: "For her the point represents the central point of a reality and of all the elements of the reality: man in his nothingness and infinity; the created in its minuteness and immensity; God in his immanence and transcendence. ${ }^{.28}$

One of the most influential, though today forgotten, books in the history of Christian philosophical theology is the mysterious Hermetic treatise called the Book of the Twenty-Four Philosophers, a collection of definitions of God supposedly composed by a colloquium of unnamed philosophers that circulated along with two commentaries. The book first appeared in the twelfth century and includes much ancient lore, though I doubt the claims that it goes back to late antiquity. ${ }^{29}$ The most famous of the enigmatic definitions given is the second: "God is the infinite

w The edition of Julian used here is The Writings of Julian of Nonwich, ed. Nicholas Watson and Jacqueline Jenkins. University Park: Pennsylvania State University, 2006, Chap. 11.1-4 (ed., 163). I have made my own translations.

2 Chap. 11.7-10. In Chap. 64.19-23 (ed., 325) Julian has reflections on the temporal poynt or instant of time in which we are called to judgment that echo those of the Cloud author about the athomus.

s Roland Maisonneuve, "Julian of Norwich and the Prison of Existence," Studia Mystica 3 (1980): 26-32 (quotation at 32). See also Carmel Brendon Davis, Mysticism and Space. Washington, DC: Catholic University Press, 2008, 127-36.

Claims for a late antique Greek original are advanced in the "Introduction" to the critical edition of Françoise Hudry, Liber Viginti Quattuor Philosophorum (Turnhoult: Brepols, 1997. CCCM 143A). 
sphere whose center is everywhere and whose circumference is nowhere. ${ }^{1 / 30}$ This geometico-theological definition gave birth to much cogitation and comment, being discussed by Alan of Lille, Thomas Aquinas, Eckhart, and Nicholas of Cusa, to name but a few. ${ }^{31}$ Dante also seems to have known the definition. Whoever first hit upon this pregnant attempt to "define" God seems to have been inspired by the same imperative that drove the mystics surveyed here-as well as many othersthat is, to find some way of putting into words through the transformation of spatial and temporal terms the intersection of the timeless and time that is at the essence of what we call mysticism.

3) Deus est sphaera infinita [some versions read: infelligibilis] cuius centrum est ubique, circumferentia nusquam. For the axiom and the two commentaries on it, see Hudry, 7-8, and 37-39.

3 There is a large literature on the axiom. The most detailed history, though now outdated, is that of Dietrich Mahnke, Unendliche Sphäre und Almittelpunkt; Beiträge zur Geschichte der mathematischen Mystik. Halle: Niemeyer, 1937. 